\title{
Experience from continuing education using e-learning
}

\author{
Asbjørn Rolstadås
}

Received: 22 June 2010 / Accepted: 12 May 2011 / Published online: 26 May 2011

(C) The Author(s) 2011. This article is published with open access at Springerlink.com

\begin{abstract}
An e-learning approach for project management using the hybrid model has been developed, tested and improved. Two Norwegian universities have developed a continuing education programme at two levels. The client has been three industrial companies in the oil and gas sector. For delivery another two universities outside Norway has participated. The hybrid model contains two plenary sessions using traditional teaching methods. In addition there are a number of virtual sessions using technology enhanced learning including multimedia technology. In addition there is a project assignment to be solved by groups of three course participants. Experience has shown that training based on a combination of on-campus and Web-based is an effective approach. This concept may be significantly more effective than traditional programs with plenary sessions only or with virtual content only.
\end{abstract}

Keywords Technology enhanced learning · Continuing education · e-learning $\cdot$ Project management

\section{Introduction}

The industry still has a challenge to improve competitiveness and productivity. Perhaps the industry most exposed to competition is the manufacturing industry. Therefore some claim that the productivity boom is cantered in manufacturing, and that products with embedded new technologies come almost exclusively from manufacturing sector. The manufacturing sector also leads in management innovation. Concepts such as "Lean", "Six Sigma", "JIT", "Supply Chain

A. Rolstadås $(\varangle)$

Department of Production and Quality Engineering, Norwegian University of Science and Technology, 7491, Trondheim, Norway

e-mail: Asbjorn.Rolstadas@ntnu.no
Integration", etc. all have their roots in manufacturing (Duesterberg and Preeg 2003; ManuFacture 2003).

The change process in the manufacturing industry has initiated a need for improved education in manufacturing. There is a need for new curricula integrating technology, business aspects and management, and there is a need to adapt delivery of education to suit the needs of persons in daily work in industry (Moseng and Rolstadås 2002; O'Sullivan et al. 2002).

There is a growing tendency in performing business by projects (Rolstadås 2000) and the pressure for improved competitiveness has reached also the industry that is project based.

Digital business offers a radical new way of operation and the factor of 'speed to customer delight' challenges industry executives to incorporate many new approaches and activities, as it involves advanced use of information and communication technology in every link of the supply chain while simultaneously reducing cost and lead times and increasing profit (Hunt et al. 2004).

There is a need to introduce the principles of digital business to continuing education. An example of this is discussed in the following.

\section{The need for education}

Several authors have pointed to the need for an improved education in manufacturing. The IMS organization has defined five manufacturing technology platforms (MTP). One of these is "education" (IMS 2011) where IMS encourages research on "educational programs designed for an information based knowledge worker environment that supports manufacturing in the future". IMS says that "Research listed under this platform will contribute to the development 
of a coherent vision of manufacturing education across the whole vocational and professional community".

Mehrabi et al. (2002) have studied trends and perspectives in flexible and reconfigurable manufacturing systems and have identified a number of problems associated with FMS. This includes training.

Mears et al. (2009) discusses engineering curriculum development and have done a case study at Clemson University. The paper shows a table of automotive supplier perceived education need areas. One of these areas is project management.

The GEM project developed a framework for a curriculum in manufacturing strategy (Rolstadås 2007). The project arose out of the need to provide an education in manufacturing that combined technological, business and human competence. To document this, a survey was conducted in worldwide manufacturing industry. From more than 500 responses, the need for education was defined in each of the three categories. In technological competences, the needs were split on:

- Production related topics

- Product related topics

- Business operation related topics.

In the latter category, the top needs were quality management, project management, logistics management and e-work.

There is beyond doubt a need for education in manufacturing. Many companies have a strategy to maintain employees up to date and consequently encourage continuing education. In this context the focus will be on innovation management which includes project management. For a high competitive industry such as the automotive and others, there is however a need to combine education and work. This creates "students" that are off campus and have the need to select when and where to obtain learning on an individual basis. This again calls for new learning approaches including new concept for delivery of learning.

\section{Learning approaches}

The IMS 2020 project (sponsored by the European Commission) is a research set up to develop roadmaps for international intelligent manufacturing research (Taisch et al. 2010). There are roadmaps developed for five key technology areas (KAT):

- Sustainable manufacturing (KAT 1)

- Energy efficient manufacturing (KAT 2)

- Key technologies (KAT 3)

- Standards (KAT 4)
- Education (KAT 5)

In each of these areas, research topics are identified based on literature surveys, expert workshops, questionnaire surveys, wikis and interviews.

Vigtil et al. (2010) describes the roadmap for education further and identifies 9 research topics:

- Teaching factories

- Cross sector education

- Communities of practice

- Tacit to explicit knowledge transfer

- Innovation agents

- Benchmarking

- Serious games

- Personalized and ubiquitous learning

- Accelerated learning

The need for research in manufacturing education clearly demonstrates the type of learning approaches that the industry sees necessary. Some of these concepts are already well known, such as teaching factories, communities of practice and serious games. In project management communities of practice and serious games are the most appropriate.

Communities of practice are well suited for e-learning approaches where learners across organizational boundaries cooperate and forms small learning communities. Such communities will also utilize social media in their process, especially since learning normally takes place outside office hours and at the home base. Chu et al. (2010) has studied communities of practice model driven knowledge management. They claim that communities of practice provide a systematic way of addressing the kind of dynamic "knowing" that makes a difference in practice and stimulates people to create, refine, communicate and share knowledge. Chu et al. (2010) have developed a model to understand the organizational culture with four business strategies: innovation, responsiveness, core competency, and efficiency.

Serious games are particularly well suited for project management education outside a classroom setting. It can foster teamwork and at the same time create a competitive environment. In project management effective decision making is crucial and often has to be executed under time pressure. Training in a virtual environment that can be offered through a serious game is consequently well suited. Oliveira et al. (2006) has studied the impact of serious games in European industry. They have found that gamers show evidence of being more competitive than non-gamers. Although there is little evidence of a difference in ambitions between gamers and non-gamers, gamers tend to have a stronger drive to accomplish goals.

The IMS 2020 research also showed a need for personalized and ubiquitous learning (Vigtil et al. 2010). This is a 
strong argument for more focus on e-learning — a view that is shared by O'Sullivan et al. (2009). They say that education has a significant role to play in the success of the manufacturing organizations and that there are two sides to learning: creating courses and finding effective ways to deliver the content of the courses.

The GEM project developed a demonstrator with 5 learning modules experimenting with different e-learning concepts (Schwesig et al. 2005). One of them was a web-based group simulation game. The demonstrators were tested by delivering to a target group and evaluating their outcome. In total there were 500 tests. The learners appreciated the content of the courses as quite good, but would have appreciated a greater variety of interactive elements. They liked the instructional structure, especially the frequency of interactions. According to the screen design, the simplicity and cleanliness of the design has been appreciated most, while the quality of media elements and graphics were evaluated controversially. The greatest part of the users appreciated the quality the graphics and the value added by them, while the quality of video/audio elements were rated worse. An explanation to the low quality of the videos could be that they were not made using professional equipment and personnel.

Hussein and Rolstadås (2002) have applied a concept which they refer to as hybrid learning. This solution is recommended to be used to deliver education for an organization with a large number of people that are distributed over a large geographic area. In addition, the target group for a hybrid solution is characterized by having a diverse social, cultural and academic background. Therefore, it is fundamentally important that the model addresses multiple learning styles. Multimedia and technology are used increasingly to accomplish this challenge. Multimedia is the use of text, graphics, animation, picture, video, and sound to present information. All of the above can now be integrated using a computer and delivered over the World Wide Web.

The hybrid model has the following properties:

- It offers an environment for learning that address multiple learning styles

- It allows active participation

- It enables the learners to build personal social networks

- It allows the use of ICT for designing the content in order to enrich the learning experience

- It limits the need for on-campus delivery

Hybrid learning involves a mix between plenary and virtual sessions. A plenary session is based on traditional teaching methods such as lectures, assignments and group work. A virtual session is based on material that enables the course participant to select time and place for learning within certain limitations.
The following pedagogic approaches may be applied:

- Real lectures

- Video lectures

- Virtual lectures

- Reading assignments

- Group assignment

- Group work

- Individual assignment

\section{Research approach}

The research approach is action research. The researcher has been working with development and delivery of e-learning courses for multinational large companies over a period of 10 years. In total there are 40 courses with a total number of participants of 927 . The courses have two or three plenary sessions. After each plenary session an evaluation is done using a questionnaire. The findings are based on analysis of the responses to the questionnaires.

The first development was a prototype that was tested. This has been continuously improved for each year. In the beginning there were five universities involved in the education. This was later reduced to three universities.

There are three enterprises that have participated in defining the education need. Most of the courses have been for these companies. However, it has later been transferred also to other industries.

Two of the universities (based in Norway) had the responsibility of developing all the training material. This had to match a set of requirements and curricula specifications that were developed jointly by the three industrial companies and the two developing universities. There was extensive collaboration with frequent interactions between the universities and also between the universities and the companies. In this way the curriculum matched well with the needs of the industry, and at the same time the industrial managers learned how new teaching technology could be utilized to improve their business performance.

One of the developing universities was a technical university. The other developing university was a management school. Two of the industries were oil companies using project management competence for their oil and gas development projects in the North Sea. The third industry was a major supplier in process engineering and steel erection within the offshore sector.

An important design criterion was that the education should have an international profile. Therefore three universities (from UK and Canada) in addition to the two developing universities were involved in the execution of the education program. 
The effect of an e-learning approach has been studied using the evaluation sheets for a course in project management for the period 2006-2010. The course exists in two versions: an essential version aiming at project managers with little or no experience and an advanced version aiming at project managers for large projects with more than 10 years of practical experience in project management.

An evaluation is performed after each session. There data covering 12 sessions for the advanced course. The number of participants for each course is 20-24. For the essential course, there are data from 17 sessions with 25-32 participants in each course. For the advanced course the number of participants was intentionally kept low (not exceeding 24) to allow a high degree of interaction. The participants learnt a lot from each other and the role of the teacher became more like that of a facilitator or moderator. The essential course was more a traditional teacher-student relationship with lectures. Again interaction was considered important and this was the reason for a target number of 30 participants for each course.

The questionnaire used is the same for the essential and advanced course. However, for the first years a different variant was used. Results from these four sessions have been adapted to fit the rest of the questionnaires. There are four parameters from the questionnaires that have been selected to evaluate the e-learning approach:

- Relevance - to which degree did the participants find the course relevant for their work

- Teaching method-how was the quality of the learning approach evaluated

- Supervision-to which degree were the participants satisfied with the academic supervision they received

- Satisfaction-what was the overall satisfaction with the course?

Scoring was on a scale from 1 to 6 with 6 as the best value.

\section{The case}

The case represents an e-learning development in project management and where advanced technology was applied. The three industries involved needed a new learning approach to enhance the competence of their project participants and project managers. On the university side, the drivers were two developing universities in cooperation with three other international universities.

The education program was tailor made to the participating industries. There were two different education levels, each with a program equivalent to 15 ECTS:

- Basic level

- Advanced level
Pilots were developed and tested for both levels. They were revised after the pilot run based on feedback and then delivered on a regular basis for a period.

The contents comply with the PMI standard PMBoK (PMI 2008). However, it was heavily amended based on current international literature in the field (Harrison 1992; Hartman 2000; Kerzner 2002; Turner 1999; Rolstadås 2008).

The selected delivery mechanism for the education was the hybrid approach (Hussein and Rolstadås 2002). The mix between plenary and virtual sessions is depicted in Fig. 1.

Each plenary session is scheduled for three full days. It is underlined that education should be interactive and aiming at activating students. This means that less time is spent for lecturing and more for training through group work.

Each virtual session contains an equivalent of 3 days classroom education. The session is however distributed over a period of three weeks. During these three weeks the actual professors are available for communication either via e-mail, Internet, fax or phone.

For each topic in a virtual session the time is typically split in three blocks:

- Lectures which are done by reading assignments, video lectures, slide-shows, computer games, etc

- Assignments which are tasks that the students shall work with in groups and in a virtual environment using advanced ICT

- Client lectures which is mostly reading assignments where the students are familiarized with company policy or practice or with examples of application of the theory

A standard virtual classroom is used. In this instructions are given, lecture notes, assignments or other training material is distributed and discussions are conducted. Participants can be addressed either as individuals, groups or the whole class.

In parallel with the various sessions, there is a project assignment. This comprises literature studies, problem description, and problem solution connected to the topics lectured. The report is written as a research report putting emphasis on discussion of alternatives before conclusions are reached. There need to be adequate references to literature. The project is carried out by groups of three participants that should work together from different geographical locations. There is assigned one supervising professor and one industrial mentor to each group.

The course is terminated with a written home examination over Internet. This is graded. The project assignment, individual assignments and project presentations are also graded, and a total degree is given. A certificate is issued.

Success criteria for designing the course were based on guidelines from Hussein and Rolstadås (2002): 


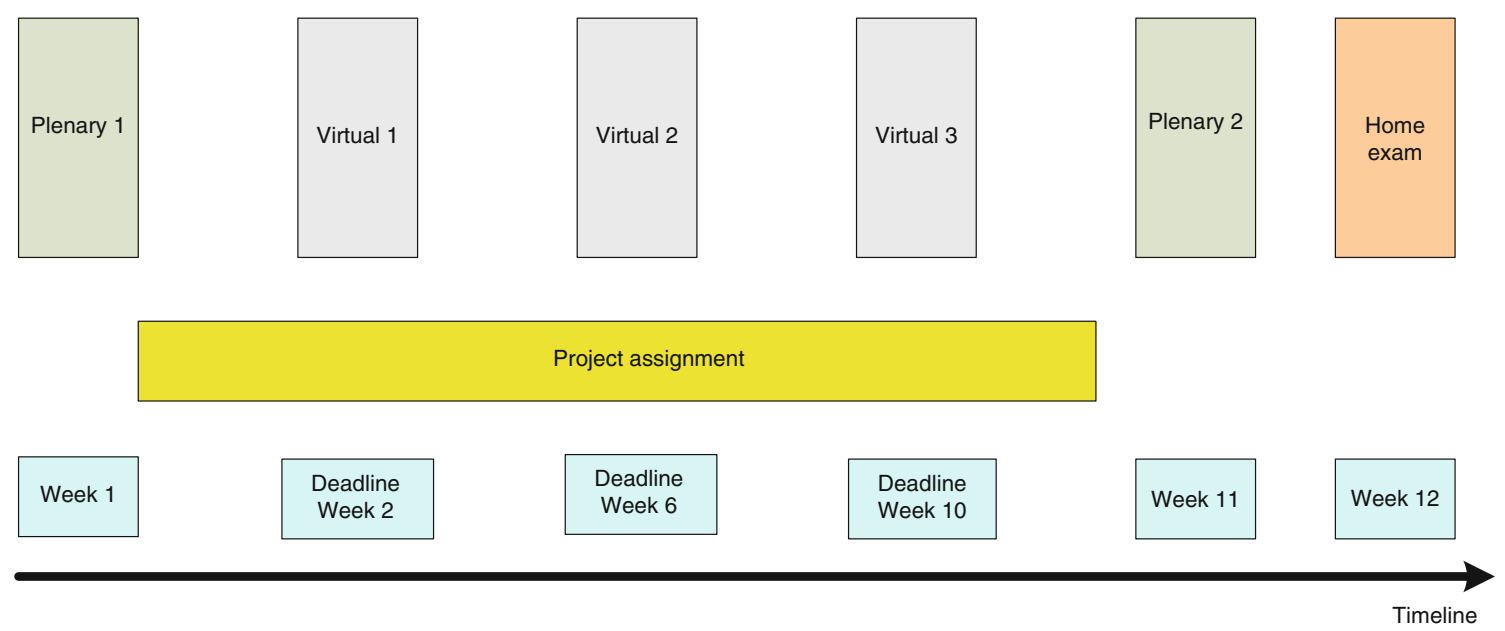

Fig. 1 Session composition

- Target group of the hybrid solution is learners with high competence in their field of expertise, tutors, instructors and facilitators must bring this experience into focus when designing the content.

- The distribution of topics along the web based and on-campus phases must be considered carefully. This distribution should not be arbitrary. The rule of thumb is lessons that require high level of interactivity between the learners should be prioritized in the on-campus sessions.

- Advances in technologies should be used in order to enrich the learning experience of the learners. This in particular applies in the web-based phases. The learners should see and feel what the "added value" of using the World Wide Web is.

- Availability in the form of an updated support system that assists the learners on the academic, technical, and administrative level. This again applies in particular for the web-based sessions.

- Self-disciplined and motivated learners are an important factor for the success of the program. In this regard both the instructor/facilitator and the sponsor have great responsibility in keeping the motivation high through persistent follow up and monitoring.

\section{Evaluation results}

Figure 2 shows a graph with the evaluation figures. The scores form the advanced and the essential courses are indicated separately.

The courses score quite high on all the four criteria. This indicates that the learning approach is successful. For the advanced courses, the teaching method has an average score of 4.72. It varies between 4.21 and 5.21 giving a variance of totally 1.00 .

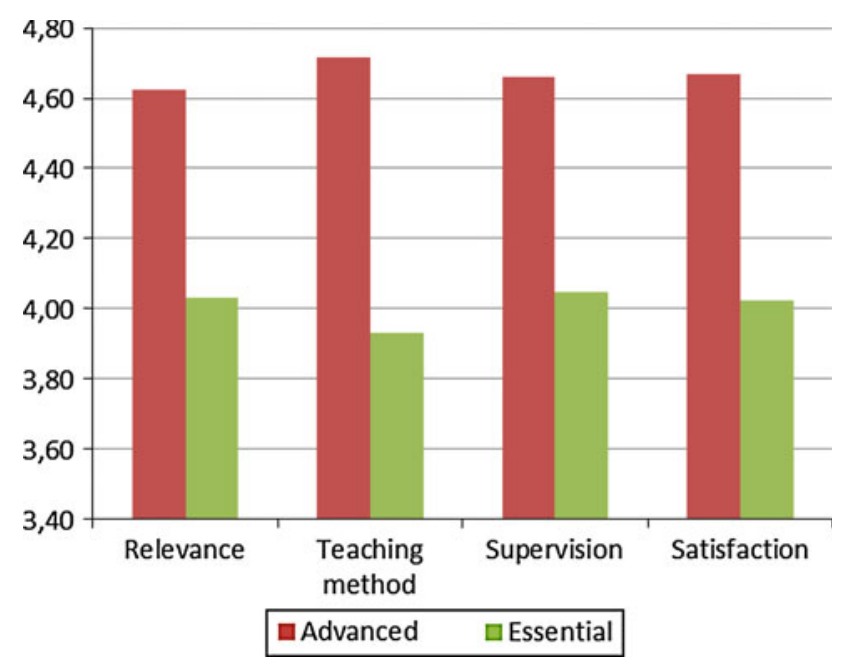

Fig. 2 Evaluation results for project management courses 2006-2010

What may be surprising is that the essential courses scores significantly lower than the advanced courses. There may be two explanations to this.

First, the course participants have different previous experience as project managers. This of course influences their ability to reflect and work on their own. The less experienced, the more support is needed through presence of a professor and ability to discuss amongst themselves. Also the teaching method reflects a difference in course level. In the essential courses, a more classroom teaching is applied transferring knowledge from the professor to the participant. For the advanced courses a coaching approach is applied. The role of the professor to a larger extent becomes that of a moderator and the participants share their experience for mutual learning.

Second, a study of the raw data indicates that the quality of the earlier courses is lower than for the more recent courses. 
In other words, there has been a pedagogical development over time. This postulate is supported by the fact that the direct variance for the essential courses is much larger than for the advanced courses. The direct variance (the difference between the max and min values) is 1.11 for the advanced courses and 2.57 for the essential courses. If data for only the last 3 years are used, the average scores for the teaching method are 4.71 and 4.29 respectively for the advanced and the essential courses.

A potential for improving the scores on the essential course could be to move the learning more in the direction of the coaching approached used in the advanced course. However this is also a question about the costs that an employer is willing to carry for the execution of the courses.

\section{Conclusion}

The hybrid solution is primarily a cost effective way for delivering education. It combines multiple instructional delivery approaches that give the participants the chance to decide the time and place for their own studies and at the same gives them the chance to become acquainted with each other as well as keeping the motivation high through all phases. Experience has shown that training based on a combination of oncampus and Web-based is an effective approach. This concept may be significantly more effective than traditional programs with plenary sessions only or with virtual content only.

Open Access This article is distributed under the terms of the Creative Commons Attribution Noncommercial License which permits any noncommercial use, distribution, and reproduction in any medium, provided the original author(s) and source are credited.

\section{References}

Chu, M.-T., Khosala, R., \& Nishida, T. (2010). Communities of practice driven knowledge management in multinational knowledge based enterprises. Journal of Intelligent Manufacturing. Published online November 27, 2010.

Duesterberg, T. J., \& Preeg, E. H. (2003). U.S. manufacturing. The engine for growth in a global economy. A project of the manufacturers alliance/MAPI. Westport, Connecticut.

Harrison, F. (1992). Advanced project management: A structured approach (3rd ed.). Aldershot: Gower.

Hartman, F. T. (2000). Don't park your brain outside. Newton Square: Project Management Institute.

Hunt, I., Gardiner, K., Horan. M., \& Schwesig, M. (2004). Global education for manufacturing - an international curriculum. In Proceedings of the 2004 international IMS forum. Milan, Italy.
Hussein, B., \& Rolstadås, A. (2002). Hybrid learning in project management-potentials and challenges, PMI research conference. Seattle, USA.

IMS (Intelligent Manufacturing Systems). (2002). Five manufacturing technology platforms. Retrieved on January 3, 2011. http://www. ims.org/node/1469.

Kerzner, H. (2002). Project management: A systems approach to planning, scheduling, and controlling (8th ed.). Hoboken: Wiley.

ManuFacture (2003). European manufacturing of the future: Role of research and education for European leadership. Milan, Italy.

Mears, L., Omar, M., \& Kurfess T. R. (2009). Automotive engineering curriculum development: Case study for Clemson University. Journal of Intelligent Manufacturing. Published online October 22, 2009.

Mehrabi, M. G., Ulsoy, A. G., Koren, Y., \& Heytler, P. (2002). Trends and perspectives in flexible and reconfigurable manufacturing systems. Journal of Intelligent Manufacturing, 13, 135-146.

Moseng, B., \& Rolstadås, A. (2002). Global education in manufacturing-GEM. In Proceedings of CIRP international manufacturing education conference, CIMEC 2002. Twente, The Netherlands.

Oliveira, M., Andersen, B., Oliveira, A., \& Rolstadås, A. et al. (2006). The impact of serious games in the European industry. In Proceedings of 10th international workshop on experimental interactive learning in industrial management, Trondheim. June 11-13, 2006.

O’Sullivan, D., Rolstadås A., \& Filos, E. et al. (2009). Global education in manufacturing strategy. Journal of Intelligent Manufacturing. Published online October 15, 2009.

O'Sullivan, D., Precuo, L. E., Duffy, P., van Dongen, S., \& Guochao, X. (2002). Survey of existing manufacturing curricula. GEMEUROPE project report, Galway, Ireland.

PMI. (2008). A guide to the project management body of knowledge (4th ed.). Newton square: Project Management Institute.

Rolstadås, A. (2000). Business operation by projects. Beijing: IFIP World Computer Congress.

Rolstadås, A. (2007). Global education in manufacturing. In K.-D. Thoben, M. Taisch, \& M. Monotorio (Eds.), Advanced manufacturing — an ICT and systems perspective (pp. 229-238).

Rolstadås, A. (2008). Applied project management; How to organize, plan and control projects. Trondheim: Tapir Academic Press.

Schwesig, M., Rolstadås, A., \& Thoben, K. D., et al. (2005). An E-learning experiment in manufacturing strategy. In Proceedings from 8th IFIP world conference on computers in education. Cape Town, South Africa, July 4-7, 2005.

Taisch, M., Cassina, J., Cammarino, B., Terzi, S., Duque, N., \& Cannata, A., et al. (2010). Roadmap on innovation, competence development and education, IMS2020 project report, Milano, March, 2010. Available on http://www.ims2020.net/. Downloaded January 4, 2010.

Turner, J. R. (1999). Handbook of project based management. Birkshire: McGrawHill.

Vigtil, A., Rolstadås, A., Fradinho, M., Carpanzano, E., \& Brondi, C., et al. (2010). Methods for competence development in sustainable manufacturing. In Proceedings from conference on advances in production management, Cernobbio, Politecnico di Milano. October 11-13, 2010. 